\title{
Screening the elite chemotypes of Gloriosa superba $L$. in India for the production of anticancer colchicine: simultaneous microwave-assisted extraction and HPTLC studies
}

Devendra Kumar Pandey ${ }^{1 *+}$, Prabhjot Kaur ${ }^{1+}$, Vijay Kumar ${ }^{1}$, R. M. Banik ${ }^{2}$, Tabarak Malik ${ }^{3^{*}}$ (I) and Abhijit Dey ${ }^{4^{*}}$

\begin{abstract}
Background: Gloriosa superba L. (Colchicaceae) is a high-value medicinal plant indigenous to Africa and Southeast Asia. Its therapeutic benefits are well-established in traditional medicines including Ayurveda. It is well known for its natural bioactive compound colchicine which exhibits a wide range of pharmacological activities i.e. rheumatism, gout and was also introduced into clinical practices. The increasing demand as well as its illegal harvesting has brought this valuable plant under threatened category.
\end{abstract}

Methods: The present investigation describes a microwave assisted extraction (MAE) strategy coupled with a densitometric-high performance thin layer chromatographic (HPTLC) methodology for the analysis of colchicine from 32 different populations of G. superba. A Box-Behnken statistical design (3 level factor) has been employed to optimize MAE, in which power of microwave, time of irradiation, aqueous ethanol and $\mathrm{pH}$ were used as independent variables whereas colchicine was used as the dependent variables. Chromatography was carried out on Silica gel $60 \mathrm{~F}_{254} \mathrm{TLC}$ plates with toluene: methanol, 85:15 (v/v) being used as solvent system. Densitometric measurement was performed at $\lambda=254 \mathrm{~nm}$ following post-derivatization (10\% methanolic sulphuric acid).

(Continued on next page)

\footnotetext{
*Correspondence: dkpandey1974@gmail.com; malikitrc@gmail.com; abhijit.dbs@presiuniv.ac.in

${ }^{\dagger}$ Devendra Kumar Pandey and Prabhjot Kaur contributed equally to this work.

'Department of Biotechnology, School of Biotechnology and Biosciences, Lovely Professional University, Phagwara, Punjab 144411, India

${ }^{3}$ Department of Biochemistry, College of Medicine and Health Sciences, University of Gondar, Gondar, Ethiopia

${ }^{4}$ Department of Life Sciences, Presidency University, 86/1 College Street, Kolkata 700073 , India

Full list of author information is available at the end of the article
}

C C The Author(s). 2021 Open Access This article is licensed under a Creative Commons Attribution 4.0 International License, which permits use, sharing, adaptation, distribution and reproduction in any medium or format, as long as you give appropriate credit to the original author(s) and the source, provide a link to the Creative Commons licence, and indicate if changes were made. The images or other third party material in this article are included in the article's Creative Commons licence, unless indicated otherwise in a credit line to the material. If material is not included in the article's Creative Commons licence and your intended use is not permitted by statutory regulation or exceeds the permitted use, you will need to obtain permission directly from the copyright holder. To view a copy of this licence, visit http://creativecommons.org/licenses/by/4.0/ The Creative Commons Public Domain Dedication waiver (http://creativecommons.org/publicdomain/zero/1.0/) applies to the data made available in this article, unless otherwise stated in a credit line to the data. 
(Continued from previous page)

Results: Optimal conditions for extraction to obtain the maximum colchicine yield was found to be $7.51 \mathrm{mg} \mathrm{g}^{-1}$ which was very close to be predicted response $7.48 \mathrm{mg} \mathrm{g}^{-1}$ by maintaining microwave power (460 W), irradiation time (6.4 min), aqueous ethanol-30, pH -3. Colchicine content ranged between 2.12-7.58 $\mathrm{mg} \mathrm{g}^{-1} \mathrm{among}^{32} \mathrm{G}$. superba populations in which only three chemotypes viz. GS- 1, GS- 3, and GS- 2 collected from West Bengal and Sikkim, respectively exhibited maximum yield of colchicine.

Conclusion: Therefore, this newly developed optimized MAE coupled with HPTLC densitometry methodology not only quantifies colchicine in order to identify elite chemotypes of G. superba, but it also encourages in selecting high yielding populations of the plants for industrial use and economic boost for the farmers. This validated, simple and reproducible HPTLC protocol is being used for the first time to estimate colchicine from natural populations of G. superba obtained from 32 different geographical regions of India.

Keywords: Altitudinal variation, Chemotypes, Colchicine, HPTLC, Microwave assisted extraction, Response surface methodology

\section{Background}

Gloriosa superba L. (Family: Colchicaceae) (Fig. 1a) is herbaceous perennial semi-woody climber [1] native of tropical Asia and Africa. It is found growing all over tropical India at an altitude of 2120 meters from the North West Himalaya to Assam and the Deccan peninsula. In Karnataka, it is generally found growing all along the Western Ghats; it is also found growing in Madagascar, Sri Lanka, Indo-China and in the adjacent islands [2-4]. The genus derives its name from the Latin word gloriosus, referring to the flower. G. superba is the national flower of Zimbabwe and also the State flower of Tamil Nadu. G. superba is considered as cash crop like sugarcane and cotton due to its high returns. In 2019, the average net return per acre of the G. superba cultivation was reported about Rs. 1,499,002 per acre per crop [5].

It is also known by its trade name 'Glory lily'; in English it is known as 'Malabar glory lily' and, in Hindi and Sanskrit as 'Kalihari' and 'Agnisikha', respectively [6-8]. G. superba is a commercially imperative medicinal plant with wide range of biological activities. It is one of the prestigious herbs in Yunani system of medicine. In tropical Africa and Asia, folkloric use of the plant includes all of its parts and indigenous people exploit its value as barter from the traders [9-11]. It's most popular and widespread use in traditional medicine is manifested against rheumatism and gout [12]. The tubers of the plant are traditionally used to treat chronic ulcers, colic, bruises and sprains, haemorrhoids, leprosy, cancer, and also as a labour pain inducer [13-16]. Pharmacological properties of the tuber indicate its use as an abortifacient, as well as anthelmintic, tonic and stomachic in smaller doses. The leaves are employed to treat piles, ulcers and to expel the placenta, whereas the seeds are used to cure medical conditions in relation to cancer [17].

The medicinal value of the Glory lily is particularly due to the alkaloids especially colchicine, thiocolchicine

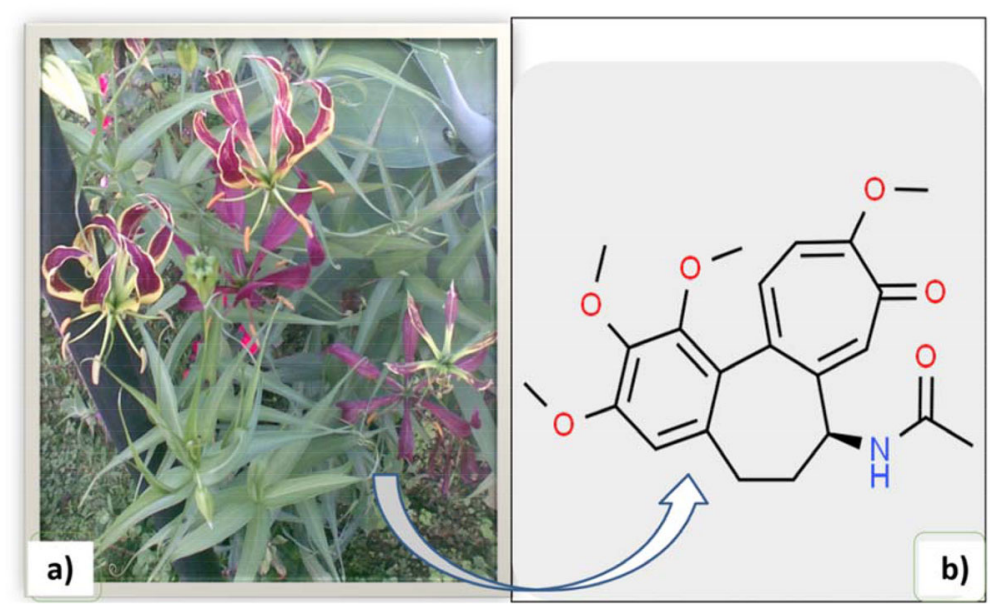

Fig. 1 a Habit of G. superba; b Structure of colchicine (from www.chemspider.com) 
and gloriosine as well as to the presence of 10 nonalkaloidal compounds viz. $\beta$-sitosterol, stigmasterol, chelidonic acid, luteolin, etc. [12, 18, 19]. Colchicine is used as a mitosis-arresting agent and is used in cancer treatment and diabetics in addition to promoting polyploidy in agricultural crops.

Colchicine (Fig. 1b) is a major alkaloid of G. superba tuber which has shown multifaceted pharmacological properties that has resurfaced since it acts at the subcellular level. Colchicine was introduced into clinical practice more than 200 years ago and is still used as an effective drug to treat gout, a common ailment in the temperate parts of the world [20]. United States Food and Drug Administration (FDA) (2009) have approved the use of colchicine in the treatment of gout. This compound is also widely utilized in the inhibition of polymerization of microtubules and inhibiting fibrosis in experimental animal models $[21,22]$. It is also used to treat cancer [23, 24], rheumatism and cardiovascular diseases [25-27]. Colchicine is found in significant quantities only in two plants viz. Colchicum autumnale and Gloriosa sp. [28]. In G. superba, colchicine yield ranges from $0.15 \%-0.3 \%$ in the rhizomes, and $0.7 \%-0.9 \%$ in the seeds [5]. The discovery of high colchicine content in this plant increased its demand in domestic and worldwide markets.

Due to the over-exploitation and indiscriminate collection and the constraints faced in field cultivation, Glory lily plant is on the verge of extinction from the wild. Therefore, it has been cited as a threatened species in the Red Data Book (2001) by the International Union for Conservation of Nature and Natural Resources (IUCN) $[1,29]$. Hence, to ensure its continuous supply and to meet the ever-increasing demand of the herbal medicine industry, screening of elite germplasms with high colchicine content and alternative approaches aiming for enhanced production of colchicine from this valuable medicinal plant are main priorities to the researchers. The identification of elite germplasms will support the use of good quality botanicals suitable for commercial cultivation of G. superba. Few reports are available on the exploration of elite chemotypes from different geographical regions of India viz. Sikkim and Gangetic plain of India [30-32]. However, very little information is available on the determination of colchicine in $G$. superba using HPTLC-densitometric analysis [31-33] which has been reported as a simple, fast and costeffective method for quantitative estimation of valuable phytochemicals [34-37].

Furthermore, quality control of crude drugs is a basic requirement for the industry and allied organizations dealing with herbal formulations or natural products. In addition, optimization and development of chromatographic profiles based on marker compounds to assist the appropriate drug production is of utmost importance. Considering the constraints of conventional extraction processes (time, energy and solvent consumption), special attention is required to optimize green and sustainable extraction methods [38]. Optimized green extraction methods produce safe and high-quality bioactive compounds in minutes with high reproducibility and low solvent consumption. In the last two decades, microwave assisted extraction (MAE) has been successfully employed as "green extraction method" for the recovery of industrially important compounds from plant matrices [39-41]. For optimization of the linear and interactive effects of different response variables, response surface methodology (RSM) is an efficacious statistical as well as mathematical design to get maximum production of value-added bioactive compounds [42-44].

Therefore, the aims of the current study are: 1) to optimize the significant variables of microwave-assisted extraction (MAE) employing RSM; 2) To analyse the intrinsic intra-specific disparity in the colchicine amount in the 32 G. superba populations collected from 32 different districts across 11 states of India using a rapid, cost-effective and validated HPTLC method; and 3) To screen the elite (high-yielding) germplasms of G. superba in order to verify and validate the quality and authenticity of the plant material in terms of colchicine content collected from different geographic locations to fulfil the ever-expanding needs of the medicinal plant markets and the pharmaceutical industries.

\section{Results}

\section{Plackett-Burman design}

Plackett-Burman design was employed for the screening of important extraction variables in order to analyse the influence of seven independent variables on the colchicine yield (Table 1). Here, the chosen designed matrix and the resulting colchicine yield from $G$. superba tuber is presented in Table 1. The influence of the parameters of extraction on the extraction of colchicine was evaluated by the methods of regression analysis (Table 2). In this, only four variables such as power of microwave, time of irradiation, solvent composition and $\mathrm{pH}$ had exhibited noteworthy influence on colchicine yield as recorded by their $P$ values at the level of $5 \%(P<0.05$ values depicted in Table 3$)$. In the present study, colchicine yield as accomplished using Plackett-Burman design has reported disparity up to 2.82-6.66 mg/g dry wt. (Fig. 2).

\section{Box-Behnken design (BBD) model fitting}

RSM is a systematic and contemporary statistical device employed in bioprocess optimization and modelling strategies where diverse design sets are used for problem 
Table 1 Plackett-Burman design and analysis of variance (ANOVA) for experimental results for extraction of colchicine

\begin{tabular}{|c|c|c|c|c|c|c|c|c|c|}
\hline $\begin{array}{l}\text { Std. } \\
\text { order }\end{array}$ & $\begin{array}{l}\text { Microwave power } \\
\text { (Watt) }\end{array}$ & $\begin{array}{l}\text { Irradiation time } \\
\text { (min) }\end{array}$ & $\begin{array}{l}\text { Particle size } \\
(\mathrm{mm})\end{array}$ & $\begin{array}{l}\text { Solvent } \\
\text { composition } \\
\text { (\%aqueous) }\end{array}$ & $\begin{array}{l}\text { Solid: } \\
\text { solvent }\end{array}$ & $\mathrm{pH}$ & $\begin{array}{l}\text { Extraction } \\
\text { steps }\end{array}$ & $\begin{array}{l}\text { Colchicine (mg/g } \\
\text { dry wt.) }\end{array}$ & Predicted \\
\hline 1 & 600 & 3 & 1 & 20 & 15 & 2 & 2 & 6.104 & 6.11 \\
\hline 2 & 600 & 9 & 0.5 & 40 & 15 & 2 & 1 & 4.980 & 5.01 \\
\hline 3 & 300 & 9 & 1 & 20 & 30 & 2 & 1 & 6.660 & 6.488 \\
\hline 4 & 600 & 3 & 1 & 40 & 15 & 6 & 1 & 2.824 & 2.88 \\
\hline 5 & 600 & 9 & 0.5 & 40 & 30 & 2 & 2 & 5.041 & 5.007 \\
\hline 6 & 600 & 9 & 1 & 20 & 30 & 6 & 1 & 5.304 & 5.476 \\
\hline 7 & 300 & 9 & 1 & 40 & 15 & 6 & 2 & 2.824 & 2.492 \\
\hline 8 & 300 & 3 & 1 & 40 & 30 & 2 & 2 & 3.624 & 3.885 \\
\hline 9 & 300 & 3 & 0.5 & 40 & 30 & 6 & 1 & 1.864 & 1.877 \\
\hline 10 & 600 & 3 & 0.5 & 20 & 30 & 6 & 2 & 4.344 & 4.102 \\
\hline 11 & 300 & 9 & 0.5 & 20 & 15 & 6 & 2 & 3.390 & 3.721 \\
\hline 12 & 300 & 3 & 0.5 & 20 & 15 & 2 & 1 & 5.224 & 5.120 \\
\hline
\end{tabular}

analysis. RSM is composed of different mathematical designs of which BBD has been applied successfully to attain the enhanced values for extraction in diverse medicinal and aromatic botanicals. Response variables possess linear, quadratic and interaction relations to elicit better yield of the coveted bioactive pharmaceuticals during the extraction process.

Hence, to confirm the influenced extraction variables as well as to calculate the response's internal variability. $\mathrm{BBD}$ is employed for computational analysis of the

Table 2 Response Surface Regression (coded units) and Analysis of Variance (ANOVA) for colchicine compound

\begin{tabular}{|c|c|c|c|c|c|c|c|}
\hline Term & Coef & SE Coef & Sum of Squares & $\mathrm{dF}$ & Mean Square & F-value & $p$-value \\
\hline Constant & 7.37333 & 0.01560 & 9.3700 & 14 & 0.6695 & 917.01 & $<0.0001^{*}$ \\
\hline A & 0.19092 & 0.00780 & 0.4374 & 1 & 0.4374 & 599.06 & $<0.0001^{*}$ \\
\hline B & 0.20350 & 0.00780 & 0.4969 & 1 & 0.4969 & 680.63 & $<0.0001^{*}$ \\
\hline C & -0.04550 & 0.00780 & 0.0248 & 1 & 0.0248 & 34.03 & $<0.0001^{\prime}$ \\
\hline D & -0.46208 & 0.00780 & 2.5600 & 1 & 2.5600 & 3509.30 & $<0.0001^{*}$ \\
\hline$A B$ & -0.05875 & 0.01351 & 0.0138 & 1 & 0.0138 & 18.91 & $0.0009^{*}$ \\
\hline$A C$ & 0.00500 & 0.01351 & 0.0001 & 1 & 0.0001 & 0.13 & 0.7178 \\
\hline$A D$ & -0.09100 & 0.01351 & 0.0331 & 1 & 0.0331 & 45.37 & $<0.0001^{\prime}$ \\
\hline $\mathrm{BC}$ & 0.01375 & 0.01351 & 0.0008 & 1 & 0.0008 & 1.04 & 0.3289 \\
\hline $\mathrm{BD}$ & 0.16700 & 0.01351 & 0.1116 & 1 & 0.1116 & 152.79 & $<0.0001^{*}$ \\
\hline$C D$ & -0.07775 & 0.01351 & 0.0242 & 1 & 0.0242 & 33.12 & $<0.0001^{\prime}$ \\
\hline$A^{2}$ & -0.95550 & 0.01170 & 4.8700 & 1 & 4.8700 & 6668.97 & $<0.0001^{*}$ \\
\hline$B^{2}$ & -0.59338 & 0.01170 & 1.8800 & 1 & 1.8800 & 2571.91 & $<0.0001^{*}$ \\
\hline$C^{2}$ & -0.41538 & 0.01170 & 0.9202 & 1 & 0.9202 & 1260.31 & $<0.0001^{*}$ \\
\hline$D^{2}$ & -0.61900 & 0.01170 & 2.0400 & 1 & 2.0400 & 2798.84 & $<0.0001^{\prime}$ \\
\hline Residual & & & 0.0088 & 12 & 0.0007 & & \\
\hline Lack of Fit & & & 0.0063 & 10 & 0.0006 & 0.5104 & 0.8086 \\
\hline Pure Error & & & 0.0025 & 2 & 0.0012 & & \\
\hline Cor Total & & & 9.3800 & 26 & & & \\
\hline
\end{tabular}

A-Microwave power; B-Irradiation Time; C-Solvent composition; D-pH Coef Regression Coefficients, SE Coef Standard Error of Regression Coefficient, Df Degree of Freedom *Very significant, where $p<0.01$ 
Table 3 Box Behnken Design (BBD) with four response variables: Microwave power (A), Irradiation Time (B), Solvent composition (C) and $\mathrm{pH}$ (D)

\begin{tabular}{|c|c|c|c|c|c|c|}
\hline \multirow[t]{3}{*}{ Run } & \multicolumn{4}{|c|}{ Response variables } & \multirow{2}{*}{\multicolumn{2}{|c|}{$\begin{array}{l}\text { Colchicine content }(\mathrm{mg} / \mathrm{g}) \text { dry } \\
\text { biomass }\end{array}$}} \\
\hline & \multirow{2}{*}{$\begin{array}{l}\text { Microwave } \\
\text { power (W) }\end{array}$} & \multirow{2}{*}{$\begin{array}{l}\text { Irradiation } \\
\text { Time (min) }\end{array}$} & \multirow{2}{*}{$\begin{array}{l}\text { Solvent } \\
\text { composition } \\
\text { (\% aqueous } \\
\text { ethanol) }\end{array}$} & \multirow[t]{2}{*}{$\overline{\mathrm{pH}}$} & & \\
\hline & & & & & Experimental & Predicted \\
\hline 1 & 300 & 9 & 30 & 4 & 5.920 & 5.703 \\
\hline 2 & 450 & 6 & 30 & 4 & 7.370 & 7.037 \\
\hline 3 & 450 & 6 & 30 & 4 & 7.410 & 6.865 \\
\hline 4 & 450 & 6 & 40 & 6 & 5.732 & 6.272 \\
\hline 5 & 600 & 3 & 30 & 4 & 5.836 & 5.953 \\
\hline 6 & 450 & 3 & 30 & 2 & 6.583 & 6.818 \\
\hline 7 & 300 & 6 & 30 & 2 & 5.980 & 5.486 \\
\hline 8 & 600 & 6 & 40 & 4 & 6.156 & 6.534 \\
\hline 9 & 450 & 9 & 30 & 6 & 6.063 & 5.917 \\
\hline 10 & 600 & 6 & 20 & 4 & 6.230 & 6.448 \\
\hline 11 & 450 & 6 & 20 & 2 & 6.780 & 6.401 \\
\hline 12 & 300 & 6 & 20 & 4 & 5.849 & 5.919 \\
\hline 13 & 450 & 9 & 30 & 2 & 6.624 & 6.340 \\
\hline 14 & 300 & 6 & 40 & 4 & 5.755 & 6.346 \\
\hline 15 & 600 & 9 & 30 & 4 & 6.159 & 5.969 \\
\hline 16 & 600 & 6 & 30 & 2 & 6.560 & 6.540 \\
\hline 17 & 600 & 6 & 30 & 6 & 5.456 & 5.917 \\
\hline 18 & 300 & 6 & 30 & 6 & 5.240 & 5.622 \\
\hline 19 & 450 & 3 & 40 & 4 & 6.110 & 5.729 \\
\hline 20 & 450 & 6 & 30 & 4 & 7.340 & 6.557 \\
\hline 21 & 300 & 3 & 30 & 4 & 5.362 & 5.598 \\
\hline 22 & 450 & 6 & 40 & 2 & 6.843 & 6.654 \\
\hline 23 & 450 & 3 & 20 & 4 & 6.234 & 5.917 \\
\hline 24 & 450 & 3 & 30 & 6 & 5.354 & 5.831 \\
\hline 25 & 450 & 6 & 20 & 6 & 5.980 & 6.861 \\
\hline 26 & 450 & 9 & 20 & 4 & 6.612 & 6.248 \\
\hline 27 & 450 & 9 & 40 & 4 & 6.543 & 6.586 \\
\hline
\end{tabular}

relations exist among diverse response variables consisting of linear, quadratic as well as 2-way interaction model based on the Eq. 1 as mentioned below. Analyses for multiple regression were carried out to produce the predicted response values $(\mathrm{mg} / \mathrm{g}$ dry wt.) for colchicine yield (Y).

$$
\begin{aligned}
\mathrm{Y} & =7.37+0.1909 \mathrm{~A}+0.2035 \mathrm{~B}-0.0455 \mathrm{C}-0.4621 \mathrm{D} \\
& -0.0588 \mathrm{AB}+0.0050 \mathrm{AC}-(9.0910 \mathrm{AD}+0.0137 \mathrm{BC} \\
& +0.1670 \mathrm{BD}-0.0777 \mathrm{CD}-0.9555 \mathrm{~A}^{2}-0.5934 \mathrm{~B}^{2} \\
& -0.4154 \mathrm{C}^{2}-0.6190 \mathrm{D}^{2}
\end{aligned}
$$

[A, B, C, D: power of microwave (A: 300 to 600 $\mathrm{W})$, irradiation time (B: 3-9 minutes), solventcomposition (C: 20\%-40\% aqueous ethanol) and $\mathrm{pH}$
(2-6) respectively which were employed as four MAE independent variables in order to achieve enhanced colchicine levels from G.superba. Experimental values of content (\%) of colchicine were evaluated by HPTL $\mathrm{C}$ methods. Table 3 exhibits the BBD along with the three different independent variables at three different levels and the experimentations besides the anticipated value acquired from colchicine yield. The predicted values obtained from colchicine were correlated with the actual experimentation values. The values for colchicine ranged from $3.445 \mathrm{mg} \mathrm{g}^{-1}$ to $7.445 \mathrm{mg} \mathrm{g}^{-1}$. Response surface plots showing interaction between different independent variables are presented in Figs. 2 and 3. 


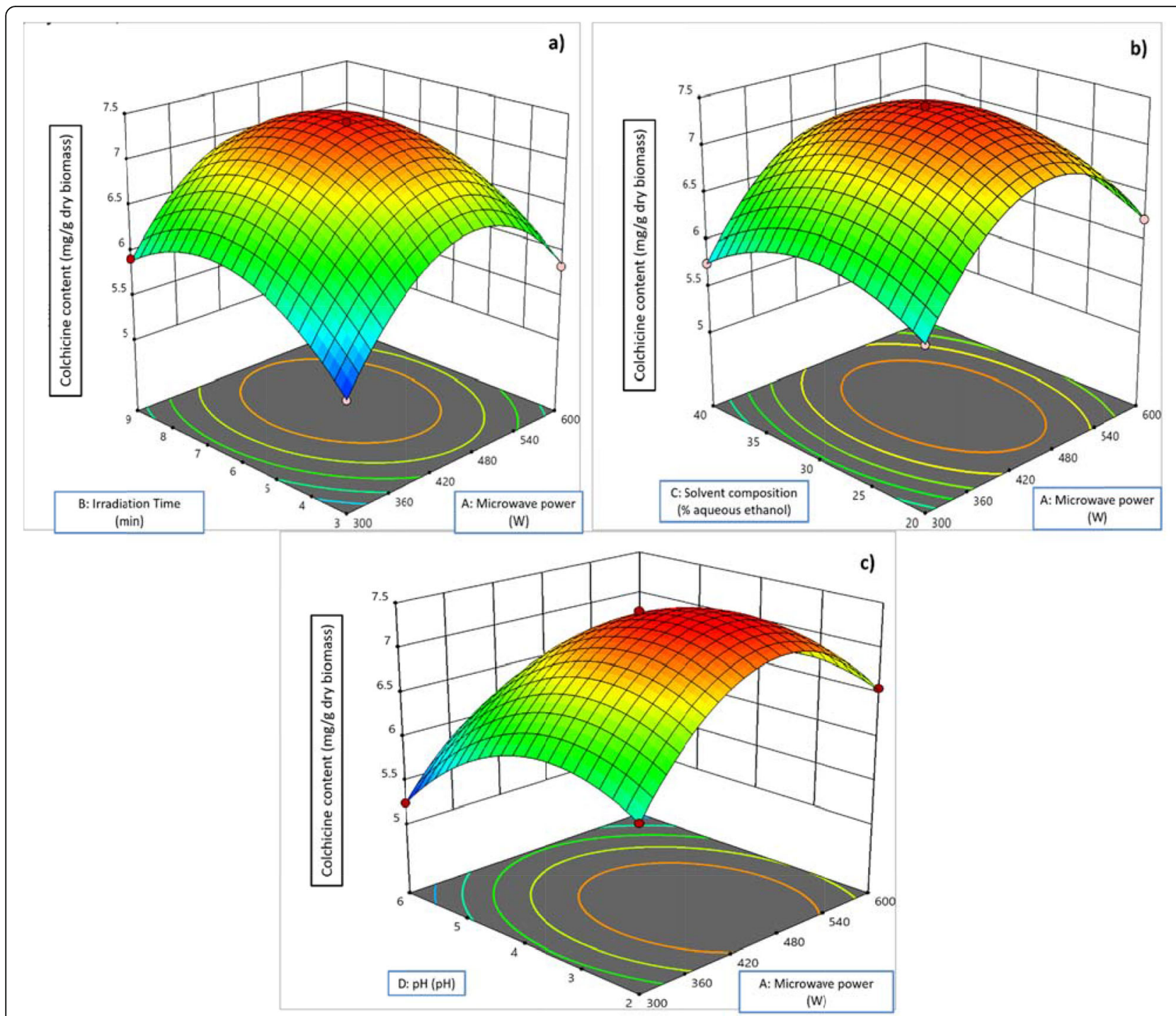

Fig. 2 Response surface plots showing interaction between microwave power and irradiation time (a); microwave power and solvent composition (b); microwave power and $\mathrm{pH}$ (c)

\section{Fitting the model}

Analysis of variance (ANOVA) was calculated for the fitness probability based upon quadratic equations of second-order (Eqs. 1 and 2). ANOVA scores recorded for linear, quadratic as well as interaction for independent variables are exhibited in Table 2 .

The probability $(P)$ value was assumed highly significant that exhibits lesser than 0.01. Values lesser than 0.05 were noted significant and were reckoned in quadratic equation. $P$ values greater than 0.05 were not considered in the quadratic equation as they were nonsignificant.

The usefulness of the model in explaining all the variations was indicated by the determination coefficients $\left(R^{2}\right)$ of 99.9 respectively. It was assumed that the proximity of the quality of $R^{2}$ to 1 indicates superior fitment of the model of experimentation to the actual data. On the contrary, lesser the $R^{2}$ value, the slighter relation the dependent variables in the model possess in order to explain the independent variables' behaviour.

For colchicine yield, the linear effect of the power of microwave (A) was reported to be statistically $(P \leq 0.00)$ noteworthy (Table 3 ). The negative quadratic influence of power of microwave $\left(\mathrm{A}^{2}\right)$ complied with the extraction yields' deceleration. Considering the time of extraction (B), there was a positive linear effect, which confirms that the compound yield is directly proportional to the increase in time. The negative quadratic influence of the time of extraction $\left(\mathrm{B}^{2}\right)$ proves the 


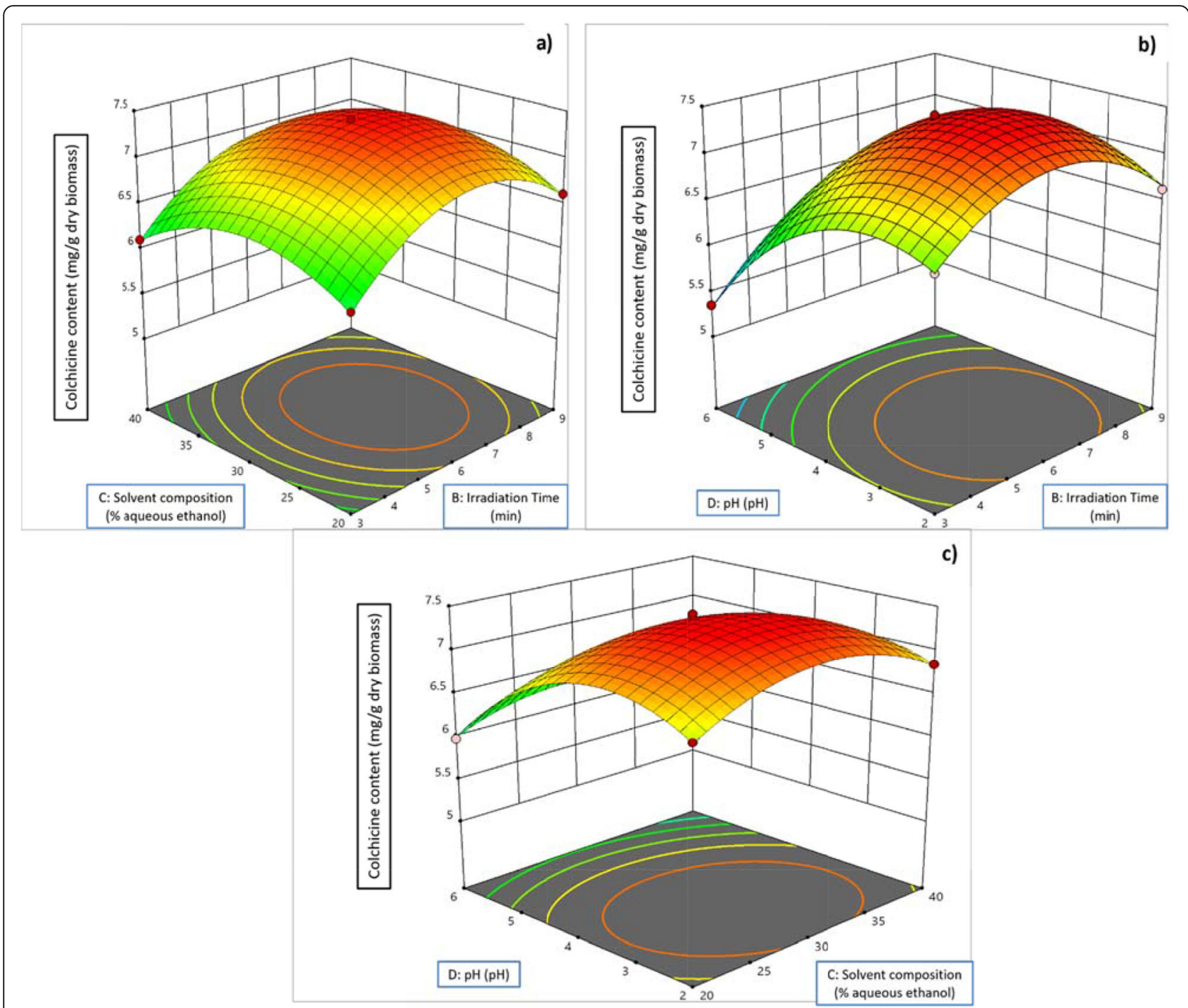

Fig. 3 Response surface plots showing the effects of interaction between irradiation time and solvent composition (a); irradiation time and pH (b); solvent composition and $\mathrm{pH}$ (c)

reduction in the extraction yield following the Fick's second law of diffusion. With relation to the solid-solvent ratio $(\mathrm{C})$, all responses exhibit the positive linear as well as negative quadratic effects. The interactive relations between microwave power " irradiation time, irradiation time * $\mathrm{pH}$, irradiation time * aqueous ethanol, irradiation time * pH and aqueous ethanol * pH for colchicine yield were significant. The graph exhibiting the main influence of the independent variables for colchicine yield are presented in Figs. 2 and 3.

As shown in Figs. 2 and 3, the optimized conditions for extraction using microwave i.e., microwave powerirradiation time-aqueous ethanol, $\mathrm{pH}$ for the better yield of colchicine were found to be irradiation time
(6.4 min), microwave power (460 W), aqueous ethanol (30\%), pH (3). At these optimized parameters for microwave extraction, maximum predicted yield achieved for colchicine was found to be $7.51 \mathrm{mg} \mathrm{g}^{-1}$ which was very close to be predicted response 7.48 $\mathrm{mg} \mathrm{g}^{-1}$ respectively.

\section{HPTLC analysis}

Preparatory TLC investigations certified the use of toluene-methanol solvent system $[85: 15(\mathrm{v} / \mathrm{v})]$ as ideal mobile phase that resulted in a clear band for colchicine at $0.27 R_{\mathrm{f}}$ value besides generating spots that were well-resolved for the analysed samples (Fig. 4). The spots were recorded at $254 \mathrm{~nm}$ following 

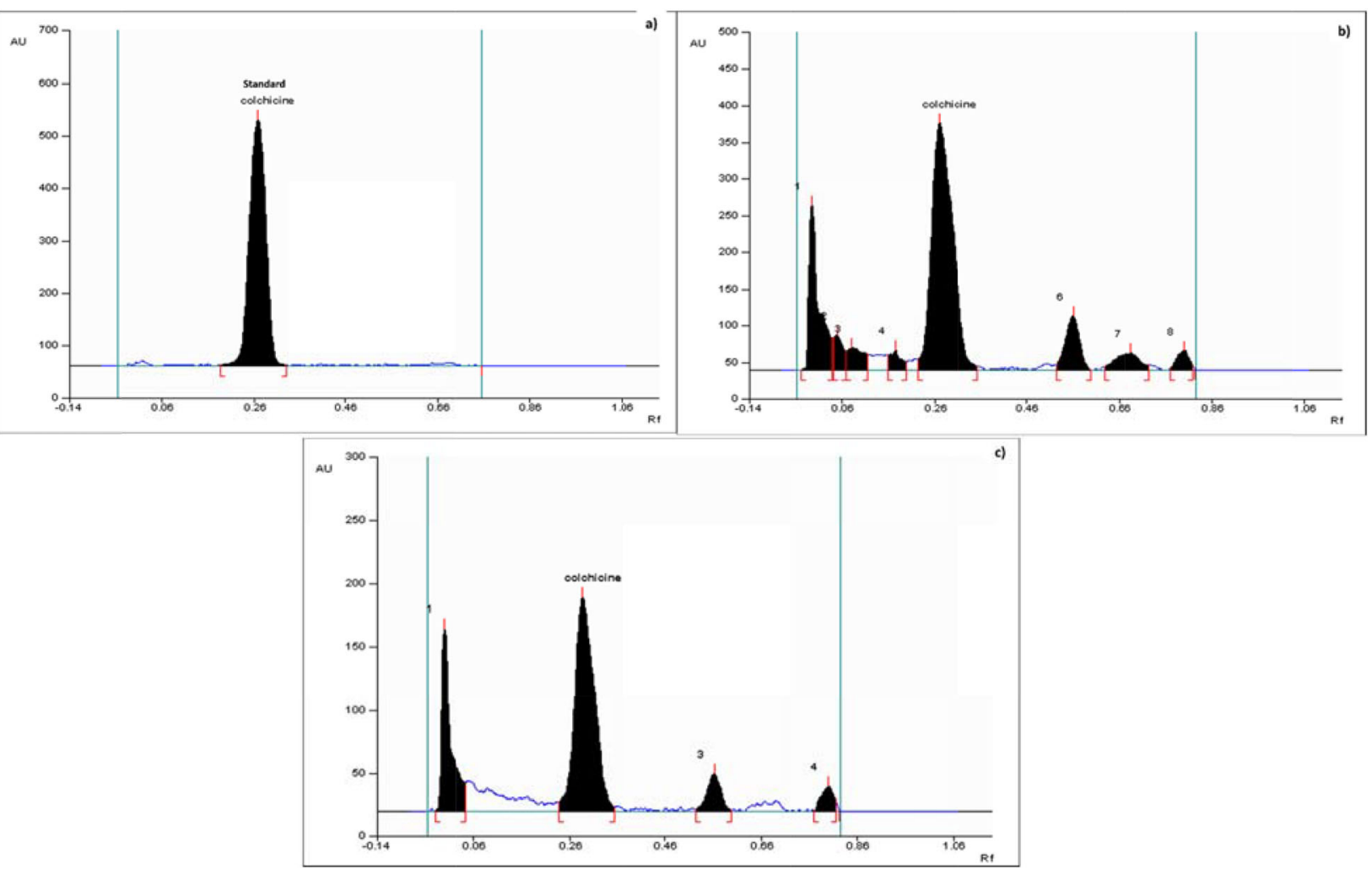

Fig. 4 a Densitogram obtained from standard colchicine, $\mathbf{b}$ and $\mathbf{c}$ Densitograms obtained from different populations of $G$. superbacollectedfromdarjeeling (West Bengal) and Gangtok (Sikkim)

methanolic $\mathrm{H}_{2} \mathrm{SO}_{4}$ [10\% (v/v) spraying]. Preliminary HPTLC fingerprinting was conducted on the standard compound and optimization of the parameters was performed. Under similar parameters, the patterns of fingerprinting for the samples were documented. At $R_{\mathrm{f}}$ 0. 27, colchicine was recorded to be present. The patterns of the 3-D densitogram of the standard and the samples showed superimposable peak corresponding to the $R_{f}$ value of 0.27 . Exact matching of the characteristics spectrum in relation to this peak was also noticed, specifying the compounds in correspondence with the $R_{f}$ value of 0.27 for the test samples and the standard being identical. The colchicine spectrum was found to overlay with the corresponding peak from plant samples that is presented in Fig. 5a. Peak purity was verified by matching the absorption spectra of the test samples and the standard; intelligible superimposibility reflected the peak purity (Fig. 5b). The calibration curve linearity was achieved between 1000-5000 ng in which the correlation coefficient was reported to be 0.97 . The regression equation for the calibration plot was $\mathrm{Y}=9178+4.527 * \mathrm{X}$. The linear regression results are presented in Table 4.

\section{Method validation}

Validation of the present HPTLC methodology was carried out for accuracy, repeatability and precision (Table 4). The present method was found to be specific for colchicine since it resolved the compound $\left(\mathrm{R}_{\mathrm{f}}\right.$ $=0.27$ ) well in the existence of other phytochemicals in G. superba (Fig. 4). The relationship between response i.e., peak area and colchicine amount ranging from 1.0 to $5.0 \mu \mathrm{g}$ per band was found to be linear and the correlation coefficient was found to be 0.97 (Table 4). Same spot of colchicine was scanned ten times $(\% \mathrm{CV}=0.44)$ in order to study instrument precision.

Eleven applications of the identical standard solution (\% $\mathrm{CV}=0.58$ ) was used to find out the repeatability of the method. By addition of known colchicine amounts to tuber extract, the method accuracy was evaluated at three different levels viz. 50, 100, and 150\%. Recovery at the three levels was noted as $100.17 \%, 99.87 \%$, and $100.2 \%$, respectively (Table 5). Precision and repeatability were determined by the assessment of intra-day as well as interday variations which were observed to be insignificant. The \% RSD was found to be $0.37 \%$ and $0.51 \%$ respectively (Tables 5 ). The method specificity 

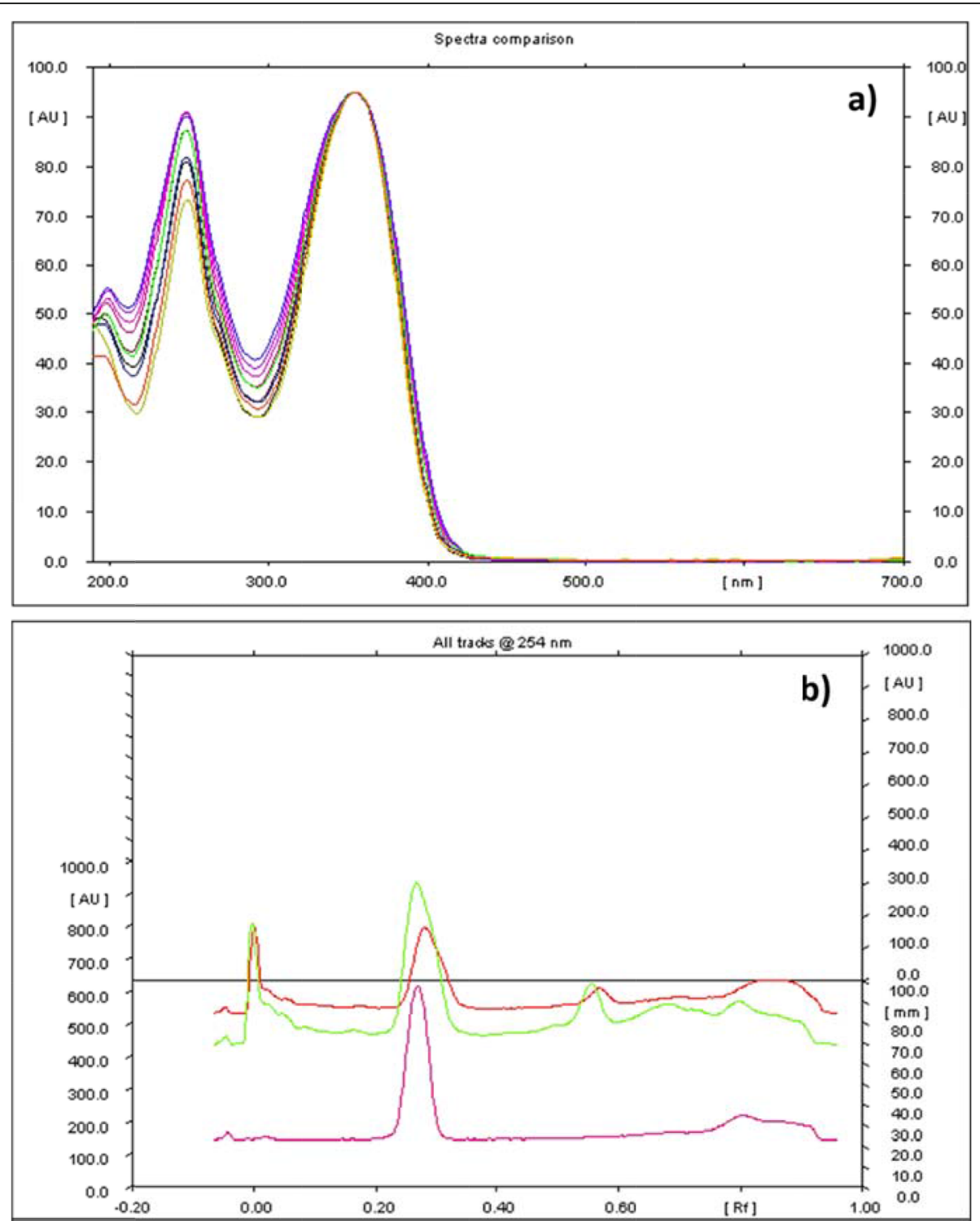

Fig. 5 a Spectrum of colchicine overlaid with the corresponding peak from different populations; $\mathbf{b}$ HPTLC (overlay) of different populations of G. superba with standard colchicine

was evaluated by furnishing the standard colchicine spectrum and the peak in correspondence associated with the samples in a range of $400-800 \mathrm{~nm}$. The spectra (Fig. 5) derived from the pure marker compound and the marker present in tuber powder were matching precisely, exhibiting no influence of other phytochemicals. The LOD and LOQ were determined via employing the equations; $\mathrm{LOD}=3 \mathrm{XN} / \mathrm{B} ; \mathrm{LOQ}=10 \mathrm{XN} / \mathrm{B}(\mathrm{N}=$ standard deviation of the peak area of the standard; $n=3$, considered as a measure of the noise; $\mathrm{B}=$ slope of the corresponding calibration plot). The LOD and LOQ were found to be $70 \mathrm{ng}$ per band and $210 \mathrm{ng}$ per band, respectively.

\section{Quantification of colchicine in G. superba chemotypes}

The present method was used to explore the colchicine amount in the tubers of G. superba chemotypes. The peak area parameter was used to determine the content $\left(\mathrm{mg} \mathrm{g}^{-1}\right)$ of the bioactive marker and the data are presented in Table 6 . Colchicine content ranged between $2.12-7.58 \mathrm{mg} \mathrm{g}^{-1}$ among 32 G. superba populations collected from 32 different districts across 11 states of India. Total three G. superba chemotypes viz. GS- 3 (collected from Kalimpong, West Bengal) (7.58 $\mathrm{mg} \mathrm{g}^{-1}$ ), GS- 1 (collected from Darjeeling, West Bengal) (7.57 $\left.\mathrm{mg} \mathrm{g}^{-1}\right)$, and GS- 2 (Gangtok, Sikkim) $\left(7.37 \mathrm{mg} \mathrm{\textrm {g } ^ { - 1 }}\right)$ were screened as elite germplasms. 
Table 4 Method validation parameters for the quantification of colchicine

\begin{tabular}{|c|c|c|}
\hline Sr.no. & Parameters & Colchicine \\
\hline 1 & Instrument precision $[\% C V, n=10]$ & 0.44 \\
\hline 2 & Repeatability [\%CV, $n=10]$ & 0.58 \\
\hline 3 & Linearity range $\left(n g / s p o t ; n=12^{a}\right.$ & $1000-5000$ \\
\hline 4 & Correlation coefficient $\left(r^{2}\right)$ & 0.975 \\
\hline 5 & Regression equation (Linear) & $Y=9178+4.527^{*} X$ \\
\hline 6 & Calculated SD value (CATS software) & 10.27 \\
\hline 7 & bLimit of detection (LOD) (ng) [3 × SD/S] (ng/band) & 70 \\
\hline 8 & bLimit of quantitation (LOQ) (ng) [10 × SD/S] (ng/band) & 210 \\
\hline 9 & $R_{f}$ and $\lambda \max$ & $0.27 ; 254 \mathrm{~nm}$ \\
\hline
\end{tabular}

${ }^{\mathrm{a}}$ Four concentration levels in triplicate; ${ }^{\mathrm{b}} \mathrm{SD}$ is the standard deviation of the blank response and $\mathrm{S}$ is the slope of the calibration plot

Chemotypes: GS- $27\left(2.12 \mathrm{mg} \mathrm{g}^{-1}\right)$, GS- $28(2.67 \mathrm{mg}$ $\left.\mathrm{g}^{-1}\right)$, GS- $26\left(2.68 \mathrm{mg} \mathrm{g}^{-1}\right)$, and GS- $11\left(2.37 \mathrm{mg} \mathrm{g}^{-1}\right)$ collected from different locations of Punjab and Jharkhand, respectively exhibited least amount of colchicine. The results indicate a clear difference in the colchicine amounts in 32 different populations collected from 32 different geographical locations of India (Table 6). The populations collected from Eastern Himalayan region at higher altitudes possessed significantly elevated amount of colchicine than that of Western Himalayan regions and Indo - Gangetic plains. Figure 6 depicts the comparative account on colchicine content among 32 G. superba populations following HPTLC quantification. UPGMA hierarchical dendrogram was performed on the basis of colchicine content in which fourteen samples viz. GS- 1, GS- 2, GS- 3, GS- 6, GS- 7, GS- 8, GS- 14, GS- 15, GS- 17, GS- 18, GS- 24, GS- 30, GS- 31 and GS- 32 were grouped together in one cluster and rest of the eighteen samples formed the second cluster. Figure 7 presents a dendrogram based on colchicine content in $G$. superba collected from different natural habitats across India where cluster 1 represents the elite chemotypes and cluster 2 represents other plant samples. Variations in colchicine content were attributed to altitudinal variation which may be implicated to many other factors such as temperature, UVradiation, edaphic factors and many more. Polyploidy in the mountain populations of G. superba may also play a crucial role in determining the phytochemical content in the said chemotypes. The present study provides important chemical footprint in the domain of bioactive compound (colchicine) mining in $G$. superba.

\section{Discussion}

Screening and optimization of significant extraction parameters employing RSM

Present study was conducted for the optimization of non-conventional extraction method (MAE) by using Plackett-Burman and Box-Behnken design (BBD). Plackett-Burman design was employed for the screening of seven independent variables, and only four parameters viz. power of microwave, time of irradiation, solvent composition and $\mathrm{pH}$ exhibited remarkable impact on colchicine yield. BBD was used

Table 5 Precision and recoveries of colchicine from plant samples

\begin{tabular}{llc}
\hline Sr. no. & Parameters & Colchicine \\
\hline & Precision and accuracy & 0.37 \\
2 & Intra-day RSD (\%), $n=5$ & $0.37 / 0.49 / 0.51$ \\
& Inter-day RSD $(\%), n=5$ (day-1/day-2/day-3) & 7.57 \\
3 & Recovery & $4 / 8 / 12$ \\
5 & Amount of standard in GS samples $\left(\mu \mathrm{g} \mathrm{mg}^{-1}\right)$ containing highest cochicine & $11.59 / 15.55 / 19.61$ \\
6 & Amount of standards added in GS sample $\left(\mu \mathrm{g} \mathrm{mg}^{-1}\right)$ & $100.17 / 99.87 / 100.2$ \\
\hline
\end{tabular}


Table 6 Colchicine content in the G. superba collected from 32 different populations in India

\begin{tabular}{|c|c|c|}
\hline Samples & Region, state and population type & Colchicine content $\left(\mathrm{mg} \mathrm{g}^{-1}\right)$ \\
\hline GS -1 & Darjeeling (West Bengal) (wild) (West Bengal) & $7.57 \pm 0.48$ \\
\hline GS -2 & Gangtok (Sikkim) (wild) & $7.37 \pm 0.26$ \\
\hline GS -3 & Kalimpong (West Bengal) & $7.58 \pm 0.63$ \\
\hline GS -4 & Siliguri (West Bengal) & $4.32 \pm 0.30$ \\
\hline GS -5 & Kolkata (West Bengal) (wild) & $3.67 \pm 0.27$ \\
\hline GS -6 & Bhubaneswar (Orissa) (wild) & $5.90 \pm 0.24$ \\
\hline GS -7 & Koraput (Orissa) (wild) & $5.43 \pm 0.21$ \\
\hline GS-8 & Chilika (Orissa) (wild) & $6.68 \pm 0.04$ \\
\hline GS-9 & Puri (Orissa) (wild) & $4.12 \pm 0.19$ \\
\hline GS-10 & Konark (Orissa) (wild) & $4.57 \pm 0.48$ \\
\hline GS -11 & Ranchi (Jharkhand) (wild) & $2.37 \pm 0.26$ \\
\hline GS -12 & Gaya (Bihar) (wild) & $4.58 \pm 0.63$ \\
\hline GS -13 & Sitamarhi (Bihar) (wild) & $3.32 \pm 0.30$ \\
\hline GS -14 & Sonbhadra (Uttar Pradesh) (wild) & $5.67 \pm 0.27$ \\
\hline GS -15 & Chandauli (Uttar Pradesh) (wild) & $4.90 \pm 0.24$ \\
\hline GS -16 & Mirzapur (Uttar Pradesh) (wild) & $4.43 \pm 0.21$ \\
\hline GS -17 & Varanasi (Uttar Pradesh) (cultivated) & $5.18 \pm 0.04$ \\
\hline GS-18 & Lucknow (Uttar Pradesh) (cultivated) & $5.12 \pm 0.19$ \\
\hline GS-19 & Sitapur (Uttar Pradesh) (wild) & $4.57 \pm 0.48$ \\
\hline GS-20 & Dehradun (Uttarakhand) (wild) & $4.37 \pm 0.26$ \\
\hline GS -21 & Haridwar (Uttarakhand) (wild) & $4.58 \pm 0.63$ \\
\hline GS -22 & Pantnagar (Uttarakhand) (wild) & $4.32 \pm 0.30$ \\
\hline GS -23 & Hisar (Haryana) (wild) & $4.67 \pm 0.27$ \\
\hline GS -24 & Kurukshetra (Haryana) (wild) & $4.90 \pm 0.24$ \\
\hline GS -25 & Chandigarh (wild) & $3.43 \pm 0.21$ \\
\hline GS -26 & Patiala (Punjab) (wild) & $2.68 \pm 0.04$ \\
\hline GS -27 & Phagwara (Punjab) (wild) & $2.12 \pm 0.19$ \\
\hline GS-28 & Ludhiana (Punjab) (wild) & $2.67 \pm 0.27$ \\
\hline GS-29 & Amritsar (Punjab) (wild) & $3.90 \pm 0.24$ \\
\hline GS-30 & Palampur (Himachal Pradesh) (wild) & $6.43 \pm 0.21$ \\
\hline GS-31 & Solan (Himachal Pradesh) (wild) & $5.68 \pm 0.04$ \\
\hline GS-32 & Jammu (Jammu and Kashmir) (wild) & $5.12 \pm 0.19$ \\
\hline
\end{tabular}

Results (\% of dry weight) are given as mean value \pm standard deviation $(N=3)$

The values followed by the same letter are not significantly different using Tukey test $(P \leq 0.05)$

to evaluate the linear, square and interactive effects of these four MAE independent variables in order to achieve maximum yield of colchicine from $G$. superba. At these optimized microwave parameters, maximum predicted yield achieved for colchicine was found to be $7.51 \mathrm{mg} \mathrm{g}^{-1}$. Another study reported the effect of three extraction parameters (interaction of time, power and methanol concentration) on extraction of colchicine with BBD [45]. However, the conventional methods are expensive as they consume larger amount of solvents, take more time for extraction and are not eco-friendly compared to the green methods. In this present investigation, MAE exhibited better yield of colchicine consuming less time $(6.4 \mathrm{~min})$ and $30 \%$ aqueous ethanol solvent. Similar results on the green extraction were obtained using MAE and non-toxic solvents in various bioactive compounds viz. pentacyclic triterpenoids, seco-iridoids, xanthone glycosides etc. [35, 41, 43]. 


\section{Interval Plot of Colchicine content (mg g-1) \\ $95 \% \mathrm{CI}$ for the Mean}

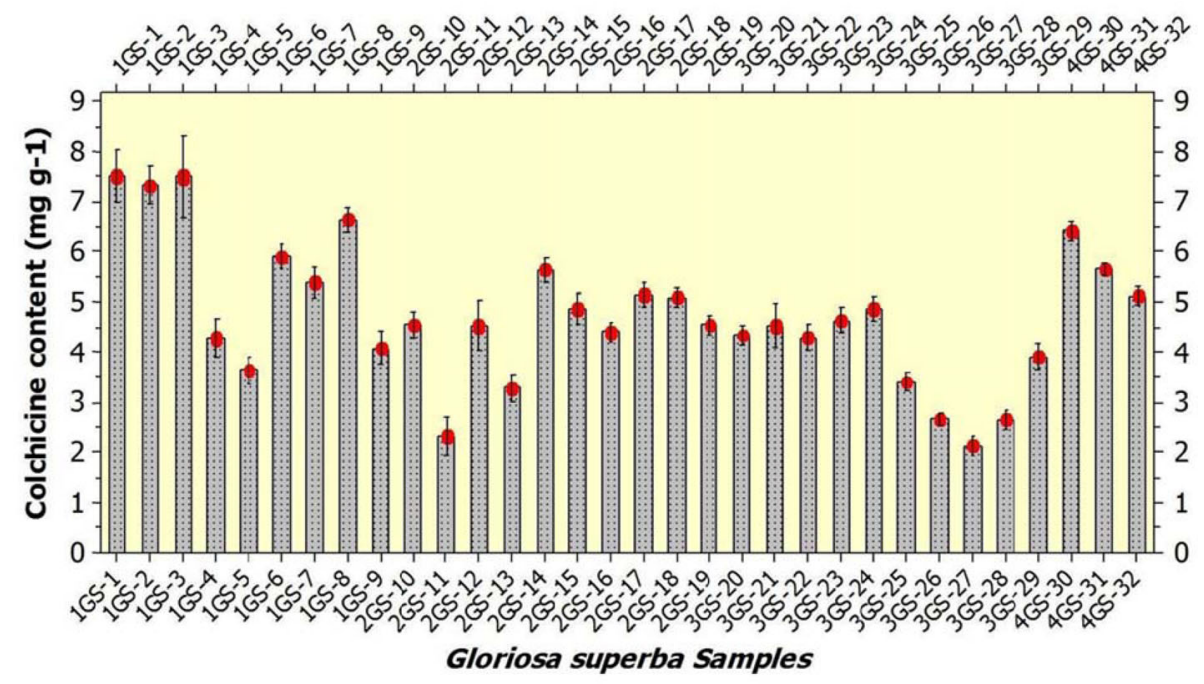

Fig. 6 A comparative account on colchicine content among 32 G. superba populations following HPTLC quantification

\section{Quantification of colchicine in G. superba chemotypes}

The chemotaxonomic study is essential to identify the elite germplasms of G. superba for the commercial exploration of targeted metabolite. In present study, validated HPTLC methodology was developed and used to screen the high metabolite yielding chemotypes in G. superba. Due to excessive exploitation and indiscriminate collection, the Glory lily population is on the verge of extinction from the wild in India. Therefore, elite chemotype(s) identified in present study will serve as a source of good quality planting material (QPM) for commercial cultivation and will meet the ever-expanding demand of the herbal pharmaceutical industry.

Earlier, colchicine content was compared in two genera of the family Colchicaceae viz. Gloriosa and Colchicum. The results indicated higher colchicine accumulation in Gloriosa (0.9\%) in comparison to Colchicum $(0.62 \%)$ [46]. G. superba is indigenous to the subcontinent and grows in regions with diverse altitudinal zones

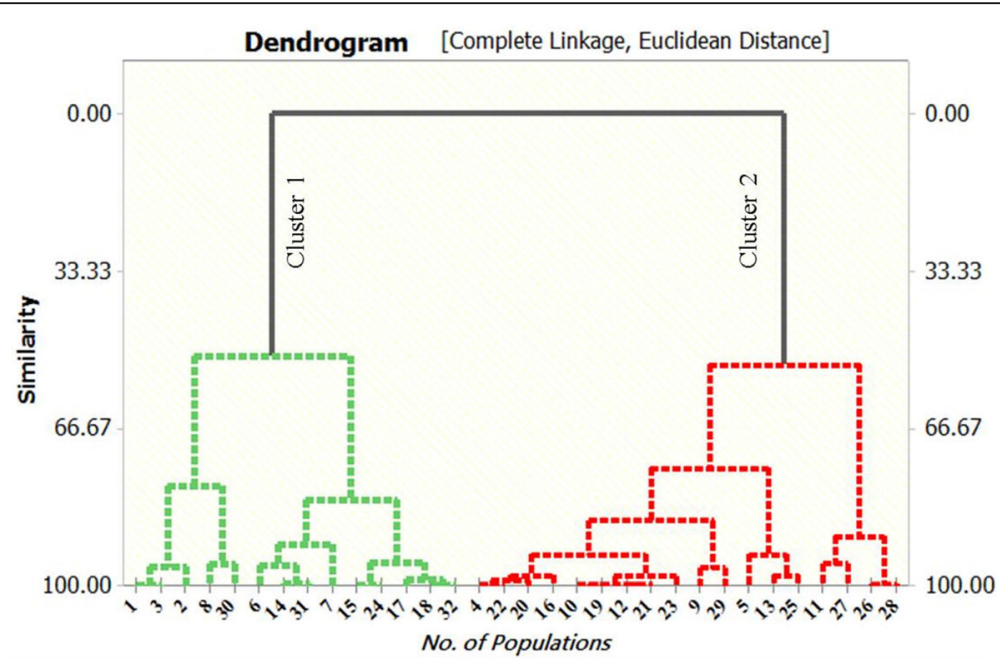

Fig. 7 Dendrogram based on colchicine content of G. superba collected from different natural habitats in India where cluster 1 represents elite chemotypes and cluster 2 represents other plant samples 
(up to $2500 \mathrm{~m}$ ). Therefore, various populations of the plant growing in different climate show variation in their metabolic profiling. Hence, such populations can be termed as chemotypes. Quantitative analysis of colchicine among $32 \mathrm{G}$. superba populations growing in an altitudinal range of $0-2045 \mathrm{~m}$ revealed that altitude plays a crucial role in colchicine content among chemotypes. Similar intra-specific modulation in the quantity of various metabolites along the altitudinal gradient has been noted earlier in diverse plant species $[47,48]$. Such altitude-influenced variation in secondary metabolite profiling was attributed to several physiological, ecological and environmental factors viz. elevated UV-B radiation, decreased temperatures and radical scavenging properties of phenolics [47, 49-56]. Misra et al. [31] also developed a HPTLC method for colchicine and gloriosine quantification in G. superba from Sikkim Himalayas. However, their study was limited to only five germplasms of G. superba. In addition, another previous study assessing the karyomorphology of G. superba collected from Siliguri, Darjeeling and Sikkim revealed that the Sikkim plants exhibited tetra ploidy while the others were diploid [57]. Therefore, higher colchicine content in uphill populations of G. superba may also be implicated to the ploidy levels of the collected samples. However, further conclusive study is needed to prove this hypothesis. In some earlier studies, natural or induced polyploidization has been correlated to the modulated quality and quantity of secondary metabolites in different medicinal plants $[58,59]$. It is well established that species growing in different altitudes show diverse biological characters varying with altitude, mainly attributed to their adaptation to different environmental conditions. In the present investigation, a significant increase in the amount of colchicine in high altitude populations may be a result of adaptation to different temperature, exposure to UVradiation, humidity, soil types and aridity.

\section{Conclusion}

In this present study, an optimized and validated method for simultaneous MAE and HPTLC-quantification of anticancer colchicine in Indian natural populations of $G$. superba was developed for identification of elite chemotypes. All statistical indications in this study support RSM as a successful tool to optimize MAE from G. superba tubers in which only four parameters such as power of microwave, time of irradiation, solvent composition and $\mathrm{pH}$ had exhibited noteworthy influence on colchicine yield as recorded by their $P$ values at the level of $5 \%$ $(P<0.05)$. The results of HPTLC study suggest that the validated method is linear, repeatable, selective, and accurate within established ranges. This developed method demonstrated prompt as well as efficient analytical technique for screening of large number of samples over short period of time. Colchicine content ranged between $2.12-7.58 \mathrm{mg} \mathrm{g}^{-1}$ among 32 G. superba populations collected from 32 different districts across 11 states of India. Maximum amount of colchicine content was reported from the samples collected from the Eastern region of India: Darjeeling- West Bengal (7.58 $\mathrm{mg} \mathrm{g}^{-1}$ ) and Gangtok-Sikkim $\left(7.37 \mathrm{mg} \mathrm{g}^{-1}\right)$ and thus screened as elite germplasms among different populations. These elite G. superba populations in terms of phytochemical content can be conserved and mass propagated by the local people. Variations in colchicine content were attributed to altitude which may be implicated to many other factors such as temperature, UV-radiation, edaphic factors etc. Polyploidy in the mountain populations of G. superba may also play a crucial role in determining the phytochemical content in the said chemotypes. The present study provides a valuable phytochemical profiling for different G. superba plant accessions which will be beneficial for pharmaceutical industries.

\section{Methods}

Plant material, reagents and standard solutions

Small parts of tubers from 32 populations of $G$. superba belonging to identical growth stage (flowering stage) were collected from diverse agroclimatic zones of India, from the sea level to $2045 \mathrm{~m}$ altitude during the year 2018-2019 (Table 7). The plants were collected from different places after taking permission from the all the landowners allowing us to sample on their private land. The plant material was identified as G. superba by Dr. R.C. Gupta, Professor, Department of Botany, Punjabi University, Patiala, Punjab. The plant material (voucher specimen no 11122018) has been stored in the Department of Biotechnology, Lovely Professional University, Phagwara, Punjab.

The tubers were air-dried at $25-32{ }^{\circ} \mathrm{C}$ and following their segmentation into small fragments to accelerate drying. In order to prepare a homogeneous powder for analysis, the dried tubers were ground to powder and the powder was passed through a sieve. The obtained powder was stored in dark at room temperature for further analysis.

HPLC grade solvents were procured from E. Merck (Mumbai, India). MilliQ PLUS purification system (Millipore, USA) was used to obtain ultra-pure water. Standard colchicine was procured from Sigma-Aldrich, USA. All analytical grade chemicals were used in the assays. Colchicine $(10 \mathrm{mg})$ was dissolved in $10 \mathrm{ml}$ 
Table 7 Geographical locations of G. superba collected from different natural habitats in India

\begin{tabular}{|c|c|c|c|}
\hline Samples & Region, state and population type & Coordinates & $\begin{array}{l}\text { Altitude (m) } \\
\text { above sea level (asl) }\end{array}$ \\
\hline GS -1 & $\begin{array}{l}\text { Darjeeling (West Bengal) (wild) } \\
\text { (West Bengal) }\end{array}$ & $27.0500^{\circ} \mathrm{N}, 88.2667^{\circ} \mathrm{E}$ & 2045 \\
\hline GS -2 & Gangtok (Sikkim) (wild) & $27.3300^{\circ} \mathrm{N}, 88.6200^{\circ} \mathrm{E}$ & 1650 \\
\hline GS -3 & Kalimpong (West Bengal) & $27.0600^{\circ} \mathrm{N} 88.4700^{\circ} \mathrm{E}$ & 1250 \\
\hline GS -4 & Siliguri (West Bengal) & $26.7100^{\circ} \mathrm{N}, 88.4300^{\circ} \mathrm{E}$ & 122 \\
\hline GS -5 & Kolkata (West Bengal) (wild) & $22.5726^{\circ} \mathrm{N} 88.3639^{\circ} \mathrm{E}$ & 11 \\
\hline GS -6 & Bhubaneswar (Orissa) (wild) & $20.2700^{\circ} \mathrm{N}, 85.8400^{\circ} \mathrm{E}$ & 45 \\
\hline GS -7 & Koraput (Orissa) (wild) & $18.8083^{\circ} \mathrm{N}, 82.7083^{\circ} \mathrm{E}$ & 649 \\
\hline GS-8 & Chilika (Orissa) (wild) & $19^{\circ} 4300 \mathrm{~N} 85^{\circ} 1900 \mathrm{E}$ & 1 \\
\hline GS-9 & Puri (Orissa) (wild) & $19^{\circ} 48^{\prime} 38^{\prime \prime} \mathrm{N} 85^{\circ} 49^{\prime} 53^{\prime \prime} \mathrm{E}$ & 0.1 \\
\hline GS-10 & Konark (Orissa) (wild) & $19^{\circ} 53^{\prime} 27^{\prime \prime} \mathrm{N} 86^{\circ} 06^{\prime} 01 " \mathrm{E}$ & 2 \\
\hline GS -11 & Ranchi (Jharkhand) (wild) & $23.3600^{\circ} \mathrm{N} 85.3300^{\circ} \mathrm{E}$ & 651 \\
\hline GS -12 & Gaya (Bihar) (wild) & $24.7500^{\circ} \mathrm{N} 85.0100^{\circ} \mathrm{E}$ & 111 \\
\hline GS -13 & Sitamarhi (Bihar) (wild) & $26.6^{\circ} \mathrm{N} 85.48^{\circ} \mathrm{E}$ & 70 \\
\hline GS -14 & Sonbhadra (Uttar Pradesh) (wild) & $24^{\circ} 41^{\prime} 23^{\prime \prime} \mathrm{N} 83^{\circ} 3^{\prime} 55^{\prime \prime} \mathrm{E}$ & 80 \\
\hline GS -15 & Chandauli (Uttar Pradesh) (wild) & $25.27^{\circ} \mathrm{N} 83.27^{\circ} \mathrm{E}$ & 70 \\
\hline GS -16 & Mirzapur (Uttar Pradesh) (wild) & $25.146^{\circ} \mathrm{N} 82.569^{\circ} \mathrm{E}$ & 80 \\
\hline GS -17 & Varanasi (Uttar Pradesh) (cultivated) & $25.2800^{\circ} \mathrm{N}, 82.9600^{\circ} \mathrm{E}$ & 81 \\
\hline GS-18 & Lucknow (Uttar Pradesh) (cultivated) & $26.8000^{\circ} \mathrm{N}, 80.9000^{\circ} \mathrm{E}$ & 123 \\
\hline GS-19 & Sitapur (Uttar Pradesh) (wild) & $27.57^{\circ} \mathrm{N} 80.66^{\circ} \mathrm{E}$ & 138 \\
\hline GS-20 & Dehradun (Uttarakhand) (wild) & $30.3180^{\circ} \mathrm{N}, 78.0290^{\circ} \mathrm{E}$ & 636 \\
\hline GS -21 & Haridwar (Uttarakhand) (wild) & $29.945^{\circ} \mathrm{N} 78.163^{\circ} \mathrm{E}$ & 314 \\
\hline GS -22 & Pantnagar (Uttarakhand) (wild) & $28.97^{\circ} \mathrm{N} 79.41^{\circ} \mathrm{E}$ & 234 \\
\hline GS -23 & Hisar (Haryana) (wild) & $29^{\circ} 09^{\prime} \mathrm{N} 75^{\circ} 42^{\prime} \mathrm{E}$ & 215 \\
\hline GS -24 & Kurukshetra (Haryana) (wild) & $29.965717^{\circ} \mathrm{N} 76.837006^{\circ} \mathrm{E}$ & 260 \\
\hline GS -25 & Chandigarh (wild) & $30^{\circ} 45^{\prime} \mathrm{N} 76^{\circ} 47^{\prime} \mathrm{E}$ & 321 \\
\hline GS -26 & Patiala (Punjab) (wild) & $30.34^{\circ} \mathrm{N} 76.38^{\circ} \mathrm{E}$ & 350 \\
\hline GS -27 & Phagwara (Punjab) (wild) & $31.22^{\circ} \mathrm{N} 75.77^{\circ} \mathrm{E}$ & 234 \\
\hline GS-28 & Ludhiana (Punjab) (wild) & $30.91^{\circ} \mathrm{N} 75.85^{\circ} \mathrm{E}$ & 262 \\
\hline GS-29 & Amritsar (Punjab) (wild) & $31.64^{\circ} \mathrm{N} 74.86^{\circ} \mathrm{E}$ & 256 \\
\hline GS-30 & Palampur (Himachal Pradesh) (wild) & $32.109722^{\circ} \mathrm{N} 76.536641^{\circ} \mathrm{E}$ & 1700 \\
\hline GS-31 & Solan (Himachal Pradesh) (wild) & $30.905^{\circ} \mathrm{N} 77.097^{\circ} \mathrm{E}$ & 1600 \\
\hline GS-32 & Jammu (Jammu and Kashmir) (wild) & $32.73^{\circ} \mathrm{N} 74.87^{\circ} \mathrm{E}$ & 350 \\
\hline
\end{tabular}

methanol to prepare a stock solution $(1 \mathrm{mg} / \mathrm{ml})$. To prepare the calibration curve, the stock was serially diluted to produce standard solutions of various concentrations.

\section{Sample preparation}

In Preliminary experimentation, one gram of shadedried powdered material from each population of $G$. superba was extracted individually with methanol (3x25 $\mathrm{ml}$ ). The individual flasks were positioned on a gyratory shaker at $100 \mathrm{rpm}$ for $6 \mathrm{~h}$. After leaving the suspension at room temperature $\left(22 \pm 2{ }^{\circ} \mathrm{C}\right)$ overnight, pooling of all extracts was carried out.

In addition, different notable extraction parameters were optimized to evaluate the effect of MAE. In this, the powdered tuber ( $0.5 \mathrm{~g}$ each) of G. superba was extracted with MAE employing a microwave oven (model: LG MC7849HS) in $100 \mathrm{~mL}$ closed vessel units by employing different extraction parameters. Filter paper (Whatman No1) was used to filter the extracts following their evaporation in vacuum employing a rotary evaporator (model: Eyela N-1100, China) to generate a solid 
mass of the extract which was then poured in methanol $(1 \mathrm{ml})$ and then it was sonicated $(10 \mathrm{~min})$. Chromatography and colchicine quantification were performed with this sample.

\section{Experimental design for MAE optimization by response surface methodology (RSM)}

Experimental designing was performed by Minitab statistical software. A two-stage experimental procedure was adopted: i) to test the significant independent parameters, Plackett-Burman design was used and ii) in order to verify the optimum level and probable interactions among important parameters, composite design was employed.

\section{Plackett-Burman model}

In order to optimize extraction of G. superba tuberderived colchicine, Plackett Burman model was employed for analysing the significant parameters.

Plackett-Burman design is based upon the following first-order model:

$$
\mathrm{Y}=\beta_{0}+\sum \beta_{\mathrm{i}} \mathrm{X}_{\mathrm{i}}
$$

(where $\mathrm{Y}$ is expected target function, $\beta_{0}$ is scaling constant and $\beta_{\mathrm{i}}$ denotes regression coefficients)

The influence of different variables viz. power of microwave $(300$ and $600 \mathrm{~W})$, time of irradiation ( 3 and 9 $\mathrm{min})$, particle size $(0.5$ and $1.0 \mathrm{~mm})$, composition of solvent (20\%-40\% aqueous ethanol), solid-solvent ratio (15 and $30 \mathrm{~g} / \mathrm{ml}), \mathrm{pH}(2$ and 6) and extraction steps (1 and 2) on colchicine extraction were investigated. Two level experiment was carried out where $(+)$ depicts maximum and (-) depicts minimum values respectively (Table 1).

Twelve experiments were conducted in duplicates to test all the above-mentioned variables (Table 1 ). The significant parameters were investigated by the analyses of regression at $5 \%$ level $(P<0.05)$ as exhibited in Table 2.

\section{Box-Behnken Design (BBD)}

During the experiments, 3 levels $(-1,0,+1)$ model of BBD with 4 factors were employed to evaluate the important parameters of MAE. Three noteworthy factors for microwave extraction such as power of microwave (A: 300-600 W), time of irradiation (B: 3-9 min), solvent composition (C: $20 \%-40 \%$ aqueous ethanol) and $\mathrm{pH}$ (26) were employed as independent variables where $27 \mathrm{ex}$ perimental runs were carried out during the experiments (Table 3). To evaluate the stability of microwave strategy and to achieve optimum colchicine yield (\%), both higher as well as lower response values were employed. BBD was applied for colchicine yield optimization from
G. superba. The RSM model response value optimization of colchicine from G. superba is performed on the basis of the following quadratic equation:

$$
\mathrm{Y}=\beta_{0}+\sum^{n}\left(\beta_{i} X_{i}\right)+\sum^{n}\left(\beta_{i i} X_{i}^{2}\right)+\sum^{n}\left(\beta_{i j} X_{i} X_{j}\right)
$$

[where $\mathrm{Y}$ is desired bioactive chemical's predicted response value, $\mathrm{n}$ is total number of independent variables with $\mathrm{n}=3, \beta_{0}, \beta_{i}, \beta_{i i}$, and $\beta_{i j}$ are intercept, linear, quadratic and interaction effects' regression coefficients respectively; $X_{i}$ and $X_{j}$.are various extraction parameters (i and $j$ as 1 to $n$ variables)]. Influence of MAE application on colchicine yield was analysed for significant variances $(p<0.01)$ (Table 3).

\section{HPTLC analysis for colchicine quantification}

The HPTLC machinery was composed three components viz. CAMAG Linomat 5 automatic sampleapplicator (Muttenz, Switzerland), CAMAG TLC scanner 3 and an attached software (CATS; version: 1.4.4.6337). TLC plates of precoated silica gel $60 \mathrm{~F}_{254}$ (Merck KGaA 1.05554. 0007; $20 \mathrm{~cm}$ x $10 \mathrm{~cm}$ in dimension and $0.25 \mathrm{~mm}$ in layer thickness) were used as the stationary phase. Samples were put in to the plates as 6 $\mathrm{mm}$ wide bands, with $10 \mathrm{~mm}$ track distance, employing the nitrogen flow equipped sample applicator provided with a $100 \mu$ l Hamilton syringe which had a defined 150 $\mathrm{nl} / \mathrm{s}$ delivery rate. The mobile phase was composed of toluene-methanol 85:15 (v/v) to achieve a development of linear ascending mode up till an extent of $80 \mathrm{~mm}$ inside a mobile phase vapor saturated twin trough glass chamber (CAMAG; $20 \mathrm{~cm} \mathrm{x} 10 \mathrm{~cm}$ ) at $22 \pm 2{ }^{\circ} \mathrm{C}$ and $50 \%$ relative humidity for $20 \mathrm{~min}$. After the development, the plates were dried for $10 \mathrm{~min}$ at 100 and were derivatized with methanolic sulphuric acid solution $[100 \mathrm{ml}$ of $10 \%$ $(\mathrm{v} / \mathrm{v})]$. Densitometric scanning was conducted at 254 $\mathrm{nm}$. The slit dimension and the scanning speed were measured at $5 \mathrm{~mm} \mathrm{x} 0.45 \mathrm{~mm}$ and $100 \mathrm{~nm} / \mathrm{s}$, respectively.

In order to analyse the linearity and calibration, marker stock solutions $(1.0,2.0,3.0,4.0$ and $5 \mu \mathrm{l})$ were employed to the plate to provide quantities from $100 \mathrm{ng}$ to $500 \mathrm{ng}$ per band. Corresponding concentrations were employed to plot the peak areas and in order to produce the calibration equation, regression analysis was performed. To analyse the underground tuber powder extract, $10 \mu \mathrm{l}$ of the obtained sample as described in section 2.2 was administered to the plate. Accepting the marker purity as $100 \%$, following the development, derivatization, scanning and peak area measurement, the content of colchicine was calculated. 
Extracts from the plant samples and the standard solutions $(1.0,2.0,3.0,4.0$ and $5.0 \mu \mathrm{l}$ ) were administered to TLC plates and were analysed by the previously described method. Following resolving the peak areas, a calibration plot was generated via peak area plotting against the standard quantity of colchicine employed. This calibration plot was applied to calculate the amounts of colchicine present in the chemotypes.

\section{Method validation}

The method validation was determined via analysing the peak purity, linearity, the limit of detection (LOD), repeatability (Table 4), percentage recovery, intra-day as well as intermediate precision (Table 5) for colchicine obtained from tubers. Each of the standard solutions of colchicine (in equivalence of 100, 200, 300, 400 and $500 \mathrm{ng} /$ band) was administered in triplicate. Against the respective colchicine amount, the peak area plotting was carried out to find the calibration plot and the linearity range was also decided. Six times scanning was performed to scan the same band for colchicine (500 ng) to check the precision of the instrument. For peak area and $R_{f}$, the mean and standard deviation with the percentage of coefficient of variation were determined. The results acquired from the investigations spotting instrument precision or repeatability is presented in Table 4. Standard solution was administered to the plate (in triplicate) and the \% CV was determined to test the repeatability evaluating the colchicine band. 50, 100 and $150 \%$ colchicine to the sample were added to test the method accuracy via ascertaining recovery at three levels. To $1.0 \mathrm{~g}$ powdered plant material containing around $0.76 \mathrm{mg}$ colchicine, standard colchicine of known amounts was added, the sample was extracted and the colchicine amounts were decided following the above-described method. Recovery was determined for all three levels (Table 5). Precision was calculated via analysing the sample solution in three bands per plate provided on three plates to determine the intra-day precision. To determine the intermediate precision, sample solution in three bands per plate was analysed on day two and \% CV was also enumerated (Table 4). The test samples' corresponding peak (in 200-800 $\mathrm{nm}$ range) in accordance to the standard colchicine's absorbance spectrum was employed in determining the method specificity. Standard solutions in different dilutions were employed using methanol (blank) to resolve the limit of detection and limit of quantification (LOD and LOQ) respectively.

\section{Acknowledgements}

Authors are grateful to the Department of Bioengineering and Biosciences, Lovely Professional University for providing lab facilities to carry out the experiments.

\section{Authors' contributions}

DKP conceptualized \& supervised the work, PK performed the experiments and wrote the manuscript, $A D$ wrote the manuscript, VK wrote the statistics part, RMB prepared tables \& prepared figures, and TM edited the manuscript. All authors have read and approved the manuscript

\section{Funding}

Lovely Professional University gave financial support but has no role in the study design, performance, data collection and analysis, decision to publish, or preparation/writing of the manuscript.

\section{Availability of data and materials}

The datasets used and/or analysed during the current study available from the corresponding author on reasonable request.

Ethics approval and consent to participate Not applicable.

\section{Consent for publication}

Not applicable.

\section{Competing interests}

The authors declare that they have no competing interests.

\section{Author details}

${ }^{1}$ Department of Biotechnology, School of Biotechnology and Biosciences, Lovely Professional University, Phagwara, Punjab 144411, India. ${ }^{2}$ School of Biochemical Engineering, Indian Institute of Technology BHU, Varanasi, India. ${ }^{3}$ Department of Biochemistry, College of Medicine and Health Sciences, University of Gondar, Gondar, Ethiopia. ${ }^{4}$ Department of Life Sciences, Presidency University, 86/1 College Street, Kolkata 700073, India.

Received: 2 August 2020 Accepted: 14 January 2021

Published online: 05 February 2021

\section{References}

1. Khandel KA, Ganguly S, Bajaj A, Khan S. New records, ethnopharmacological applications and indigenous uses of Gloriosa superba L. (Glory Lily) practices by tribes of Pachmarhi Biosphere Reserve, Madhya Pradesh, Central India. Nat Sci. 2012;10(5):23-48.

2. Anonymous. The wealth of India: a dictionary of raw material and industrial products. New Delhi: CSIR; 1956.

3. Chopra RN, Nayar SL, Chopra IC. Glossary of Indian medicinal plants. New Delhi: Council of Scientific and Industrial Research; 1956.

4. Prakash JW, Raja RD, Anderson NA, Williams C, Regini GS, Bensar K, Rajeev R, Kiruba S, Jeeva S, Das SS. Ethnomedicinal plants used by Kani tribes of Agasthiyarmalai biosphere reserve, southern Western Ghats. Ind J Trad Knowl. 2008;7:410413.

5. Ranjith Kannan R, Rohini A. Economic analysis of production and marketing of Gloriosa superba L. in Tamil Nadu. IJCS. 2019;7(3):4275-8.

6. Le Roux LG, Robbertse PJ. Tuber ontogeny, morphology and vegetative reproduction of Gloriosa superba L. S Afr J Bot. 1994;60(6):321-4.

7. Le Roux LG, Robbertse PJ. Aspects relating to seed production in Gloriosa superba L. S Afr J Bot. 1997;63(4):191-7.

8. Samy RP, Thwin MM, Gopalakrishnakone P, Ignacimuthu S. Ethnobotanical survey of folk plants for the treatment of snakebites in southern part of Tamilnadu, India. J Ethnopharmacol. 2008:115(2):302-12.

9. Harris R, Marx G, Gillett M, Kark A, Arunanthy S. Colchicine-induced bone marrow suppression: treatment with granulocyte colony-stimulating factor. J Emerg Med. 2000;18(4):435-40.

10. Suneetha MS, Chandrakanth MG. Establishing a multi-stakeholder value index in medicinal plants - an economic study on selected plants in Kerala and Tamilnadu states of India. Ecol Econ. 2006;60(1):36-48.

11. Kumar D, Kumar A, Prakash O. Potential antifertility agents from plants: a comprehensive review. J Ethnopharmacol. 2012;140(1):1-32. 
12. Jana S, Shekhawat GS. Critical review on medicinally potent plant species: Gloriosa superba. Fitoterapia. 2011;82(3):293-301.

13. Cocco G, Chu DC, Pandolfi S. Colchicine in clinical medicine. A guide for internists. Eur. J Intern Med. 2010;21(6):503-8.

14. Capistrano R, Vangestel C, Vanpachtenbeke H, Fransen E, Staelens S, Apers S, Pieters L. Co administration of a Gloriosa superba extract improves the in vivo antitumoural activity of gemcitabine in a murine pancreatic tumour model. Phytomedicine. 2016;23(12):1434-40.

15. Saradhadevi M, Gnanadesigan M, Kapildev G, Vasanth D. Dataset on antitumor properties of silver nanoparticles from Gloriosa superba (L.) seed on Dalton Lymphoma Ascites (DLA) tumor: Facile and biocompatible approach. Data Brief. 2017;14:524-30.

16. Budchart P, Khamwut A, Sinthuvanich C, Ratanapo S, Poovorawan Y, TThienprasert NP. Partially purified Gloriosa superba peptides inhibit colon cancer cell viability by inducing apoptosis through p53 upregulation. Am 」 Med Sci. 2017;354(4):423-9.

17. Shen LH, Li Y, Lai YS, Liu L. Synthesis and evaluation of nitrate derivatives of colchicine as anticancer agents. Chin Chem Lett. 2011;22(7):768-70.

18. Sugandhi R. Biodiversity conservation and patenting and property right of tribal medicine of medicinal plants of India. In: 10th Asian symposium on medicinal plants, spices and other natural products (ASOMPS X). Dhaka, Bangladesh. 2000. p. 18-23.

19. Suri OP, Gupta BD, Suri KA, Sharma AK, Satti NK. A new glycoside, 3-Odemethylcolchicine-3-O-a-D-glucopyranoside, from Gloriosa superba seeds. Nat Prod Lett. 2001;15(4):217-9.

20. Misra A, Srivastava S, Shukla PK, Kumar M, Khalid M, Kushwaha P, Agrawal PK. Variability in alkaloid and phenolic content vis-a-vis antigout potential among the natural population of Gloriosa superba (L.) collected from Central India. Nat Prod Res. 2019;14:1-5.

21. Li L, Jiang S, Li X, Liu Y, Su J, Chen J. Recent advances in trimethoxyphenyl (TMP) based tubulin inhibitors targeting the colchicine binding site. Eur J Med Chem. 2018;151:482-94

22. Bariwal J, Kumar V, Chen H, Bhattarai RS, Peng Y, Li W, Mahato RI. Nanoparticulate delivery of potent microtubule inhibitor for metastatic melanoma treatment. J Control Release. 2019;309:231-43.

23. Kozaka T, Nakagawa-Goto K, Shi Q, Lai CY, Hamel E, Bastow KF, Brossi A, Lee KH. Antitumor agents 273. Design and synthesis of N-alkylthiocolchicinoids as potential antitumor agents. Bioorg. Med. Chem Lett. 2010;20(14):4091-4

24. Dubey KK, Behera BK. Statistical optimization of process variables for the production of an anticancer drug (colchicine derivatives) through fermentation: at scale-up level. New Biotech. 2011;28(1):79-85.

25. Nakagawa-Goto K, Chen CX, Hamel E, Wu CC, Bastow KF, Brossi A, Lee KH. Antitumor agents. Part 236: synthesis of water-soluble colchicine derivatives. Bioorg Med Chem Lett. 2005;15(1):235-8.

26. Carta M, Murru L, Botta P, Talani G, Sechi G, De Riu P, Sanna E, Biggio G. The muscle relaxant thiocolchicoside is an antagonist of GABAA receptor function in the central nervous system. Neuropharmacology. 2006;51(4): 805-15.

27. Meurin P, Tabet JY. Colchicine in acute pericarditis: a new standard? Arch Cardiovasc Dis. 2011;104(8-9):425-7.

28. Varsha K, Sharma A, Kaur A, Madan J, Pandey RS, Jain UK, Chandra R. Natural plant-derived anticancer drugs nanotherapeutics: a review on preclinical to clinical success. Nanostructures Cancer Ther. 2017:775-809. https://doi.org/ 10.1016/B978-0-323-46144-3.00028-3.

29. Sivakumar G, Krishnamurthy KV. Micropropagation of Gloriosa superba L.: an endangered species of Asia and Africa. Curr Sci. 2000;78(1):30-2.

30. Misra A, Srivastava S, Kumar S, Shukla PK, Kumar M, Agrawal PK, Barik SK. Chemotaxonomic studies on natural population of Gloriosa superba (L.) collected from Gangetic plain (India) and their invitroantigout activity for the identification of elite germplasm (s). J Ethnopharmacol. 2020;249: 112387.

31. Misra A, Shukla PK, Kumar B, Chand J, Kushwaha P, Khalid M, Rawat AKS, Srivastava S. High-performance thin-layer chromatographic-densitometric quantification and recovery of bioactive compounds for identification of elite chemotypes of Gloriosa superba L. collected from Sikkim Himalayas (India). Pharmacogn Mag. 2017;13:700705.

32. Misra A, Kumar B, Shukla P, Srivastava S. Simultaneous HPTLC-UV quantification of colchicine and gloriosine alkaloids in the natural population of Gloriosa superba L., collected from Eastern Ghats of India for the identification of elite chemotypes. J Liq Chromatogr R T. 2020;13:1-10.
33. Bodoki E, Oprean R, Vlase L, Tamas M, Sandulescu R. Fast determination of colchicine by TLC-densitometry from pharmaceuticals andvegetal extracts. J Pharmaceut Biomed. 2005;37(5):971-7.

34. Kaur P, Pandey DK, Gupta RC, Dey A. Assessment of genetic diversity among different population of five Swertia species by using molecular and phytochemical markers. Ind Crop Prod. 2019;138:111569.

35. Kaur P, Gupta RC, Dey A, Pandey DK. Simultaneous quantification of oleanolic acid, ursolic acid, betulinic acid and lupeol in different populations of five Swertia species by using HPTLC-densitometry: comparison of different extraction methods and solvent selection. Ind Crop Prod. 2019;130: $537-46$

36. Kaur P, Gupta RC, Dey A, Malik T, Pandey DK. Validation and quantification of major biomarkers in 'MahasudarshanChurna'-an ayurvedicpolyherbal formulation through high-performance thin-layer chromatography. BMC Complement Med Ther. 2020;20(1):1-1.

37. Dey A, Hazra AK, Nandy S, Kaur P, Pandey DK. Selection of elite germplasms for industrially viable medicinal crop Bacopa monnieri for bacoside a production: an HPTLC-coupled chemotaxonomic study. Ind Crop Prod. 2020:158:112975.

38. Chemat $F$, Vian MA, Fabiano-Tixier AS, Nutrizio M, Jambrak AR, Munekata PE, Lorenzo JM, Barba FJ, Binello A, Cravotto G. A review of sustainable and intensified techniques for extraction of food and natural products. Green Chem. 2020;22(8):2325-53.

39. Jesus MS, Genisheva Z, Romaní A, Pereira RN, Teixeira JA, Domingues L. Bioactive compounds recovery optimization from vine pruning residues using conventional heating and microwave-assisted extraction methods. Ind Crop Prod. 2019;132:99-110.

40. Kazemi M, Khodaiyan F, Labbafi M, Hosseini SS, Hojjati M. Pistachio green hull pectin: optimization of microwave-assisted extraction and evaluation of its physicochemical, structural and functional properties. Food Chem. 2019; 271:663-72.

41. Kaur P, Gupta RC, Dey A, Malik T, Pandey DK. Optimization of salicylic acid and chitosan treatment for bitter secoiridoid and xanthone glycosides production in shoot cultures of Swertia paniculata using response surface methodology and artificial neural network. BMC Plant Biol. 2020;20:1-3.

42. Ameer K, Chun BS, Kwon JH. Optimization of supercritical fluid extraction of steviol glycosides and total phenolic content from Stevia rebaudiana (Bertoni) leaves using response surface methodology and artificial neural network modeling. Ind Crop Prod. 2017;109:672-85.

43. Kaur P, Pandey DK, Gupta RC, Dey A. Simultaneous microwave assisted extraction and HPTLC quantification of mangiferin, amarogentin, and swertiamarin in Swertia species from Western Himalayas. Ind Crop Prod. 2019;132:449-59.

44. Mohammadpour H, Sadrameli SM, Eslami F, Asoodeh A. Optimization of ultrasound-assisted extraction of Moringa peregrina oil with response surface methodology and comparison with Soxhlet method. Ind Crop Prod. 2019; 131:106-16

45. Agrawal P, Laddha K. Extraction of colchicine from Gloriosa superba tubers: a comparison of conventional and microwave-assisted extraction. J Microw Power Electromagn Energy. 2019;53(1):57-66.

46. Finnie JF, Van Staden J. Gloriosa superba L. (flame lily): micropropagation and in vitro production of colchicine. In: Medicinal and aromatic plants VI. Berlin, Heidelberg: Springer; 1994. p. 146-66.

47. Spitaler R, Winkler A, Lins I, Yanar S, Stuppner H, Zidorn C. Altitudinal. variation of phenolic contents in flowering heads of Arnica montana cv. ARBO: a 3-year comparison. J Chem Ecol. 2008;34(3):369-75.

48. Dey A, Pandey DK. HPTLC detection of altitudinal variation of the potential antivenin stigmasterol in different populations of the tropical ethnic antidote Rauvolfia serpentina. Asian Pac J Trop Med. 2014;7: S540-5.

49. Spitaler R, Schlorhaufer PD, Ellmerer EP, Merfort I, Bortenschlager S, Stuppner H, Zidorn C. Altitudinal variation of secondary metabolite profiles in flowering heads of Arnica montana cv. ARBO Phytochem. 2006;67(4): 409-17.

50. Albert A, Sareedenchai V, Heller W, Seidlitz HK, Zidorn C. Temperature is the key to altitudinal variation of phenolics in Arnica montana L. CV. ARBO. Oecologia. 2009:160(1):1-8.

51. Ganzera M, Guggenberger M, Stuppner H, Zidorn C. Altitudinal variation of secondary metabolite profiles in flowering heads of Matricaria chamomilla cv. BONA. Planta Med. 2008;74(04):453-7. 
52. Zidorn C. Altitudinal variation of secondary metabolites in flowering heads of the Asteraceae: trends and causes. Phytochem Rev. 2010;9(2):197-203.

53. Jahanbani R, Ghaffari SM, Salami M, Vahdati K, Sepehri H, Namazi Sarvestani N, Sheibani N, Moosavi-Movahedi AA. Antioxidant and anticancer activities of walnut (Juglans regia L.) protein hydrolysates using different proteases. Plant Foods Hum Nutr. 2016;71:402-9.

54. Chatrabnous N, Yazdani N, Tavallali V, Vahdati K. Preserving quality of fresh walnuts using plant extracts. LWT. 2018;91:1-7.

55. Jahanbani R, Ghaffari SM, Vahdati K, Salami M, Khalesi MR, Sheibani N, Moosavi-Movahedi AA. Kinetics study of protein hydrolysis and inhibition of angiotensin converting enzyme by peptides hydrolysate extracted from walnut. Int J Pept Res Ther. 2018;24(1):77-85

56. Habibie A, Yazdani N, Saba MK, Vahdati K. Ascorbic acid incorporated with walnut green husk extract for preserving the postharvest quality of cold storage fresh walnut kernels. Sci.Hortic. 2019;245:193-9.

57. Ghosh S, Ghosh B, Jha S. Polymorphism in Gloriosa superba. Plant Genet Resour. 2009;7(1):9-15.

58. Dhawan OP, Lavania UC. Enhancing the productivity of secondary metabolites via induced polyploidy: a review. Euphytica. 1996;87(2):81-9.

59. Salma U, Kundu S, Mandal N. Artificial polyploidy in medicinal plants: advancement in the last two decades and impending prospects. J Crop Sci Biotechnol. 2017:20(1):9-19.

\section{Publisher's Note}

Springer Nature remains neutral with regard to jurisdictional claims in published maps and institutional affiliations.

Ready to submit your research? Choose BMC and benefit from:

- fast, convenient online submission

- thorough peer review by experienced researchers in your field

- rapid publication on acceptance

- support for research data, including large and complex data types

- gold Open Access which fosters wider collaboration and increased citations

- maximum visibility for your research: over $100 \mathrm{M}$ website views per year

At $\mathrm{BMC}$, research is always in progress.

Learn more biomedcentral.com/submissions 